\title{
Presumption of sexual abuse in children and adolescents: vulnerability of pregnancy before 14 years
}

\author{
Presunção do abuso sexual em crianças e adolescentes: vulnerabilidade da gravidez antes dos 14 anos \\ Presunción de abuso sexual en niños y adolescentes: vulnerabilidad del embarazo antes de 14 años
}

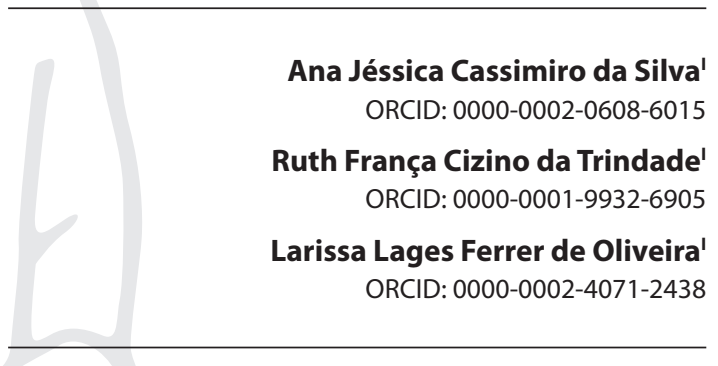

'Universidade Federal de Alagoas. Maceió, Alagoas, Brazil.

How to cite this article:

Silva AJC, Trindade RFC, Oliveira LLF.

Presumption of sexual abuse in children and adolescents: vulnerability of pregnancy before 14 years.

Rev Bras Enferm. 2020;73(Suppl 4):e20190143. doi: http://dx.doi.org/10.1590/0034-7167-2019-0143

Corresponding author: Ana Jéssica Cassimiro da Silva E-mail: anajessicacassimiro@gmail.com

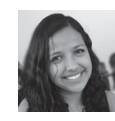

EDITOR IN CHIEF: Antonio José de Almeida Filho ASSOCIATE EDITOR: Mitzy Reichembach

Submission: 05-05-2019

Approval: 02-29-2020

\section{ABSTRACT}

Objectives: to investigate the presumption of sexual abuse through the records of live births with mothers up to 13 years of age. Methods: this is a quantitative study, with an ecological design, carried out in Maceió, with data from the Brazilian Live Birth Information System from 2009 to 2017 , based on Law 12,015/2009, on sexual crimes against the vulnerable, applying the presumption of violence in children under 14 years old. Results: nine hundred fifty-three births of children with mothers aged 10 to 13 years were recorded; $1.3 \%$ were reported as victims of sexual abuse; $20.3 \%$ declared to be married or living in a stable relationship. Records were concentrated in 04 neighborhoods, Guaxuma, Benedito Bentes, Tabuleiro do Martins, and Jacintinho. Conclusions: there was a prevalence of pregnancy and marriage in girls under 14 years of age and scarcity of reporting presumed sexual abuse by health professionals.

Descriptors: Vulnerable Populations; Pregnancy; Nursing; Adolescent; Child Abuse, Sexual.

\section{RESUMO}

Objetivos: investigar a presunção da violência sexual através dos registros de nascidos vivos com mães até 13 anos de idade. Métodos: trata-se de um estudo quantitativo com delineamento ecológico realizado em Maceió, com dados do Sistema de Informação sobre Nascidos Vivos no período de 2009 a 2017, fundamentando-se na Lei no 12.015/2009, sobre crimes sexuais contra vulnerável. Aplicou-se a presunção da violência em menor de 14 anos. Resultados: foram registrados 953 nascimentos de crianças com mães em idades de 10 a 13 anos; $1,3 \%$ foram notificadas como vítimas de abuso sexual; $20,3 \%$ declaram ser casadas ou viver em união estável. Os registros concentraram-se em 04 bairros, Guaxuma, Benedito Bentes, Tabuleiro do Martins e Jacintinho. Conclusões: constatou-se prevalência de gestação e de casamento em meninas com menos de 14 anos e a escassez de notificações de abuso sexual por presunção por parte dos profissionais de saúde.

Descritores: Populações Vulneráveis; Gravidez; Enfermagem; Adolescente; Abuso Sexual na Infância.

\section{RESUMEN}

Objetivos: investigar la presunción de violencia sexual a través de los registros de nacimientos vivos con madres de hasta 13 años. Métodos: este es un estudio cuantitativo con un diseño ecológico realizado en Maceió, con datos del Sistema de Información sobre Nacimientos Vivos en el período de 2009 a 2017, basado en la Ley 12.015/2009, sobre delitos sexuales contra personas vulnerables. Se aplican a presunción de violencia en menores de 14 años. Resultados: se registraron 953 nacimientos de niños con madres de entre 10 y 13 años; $1.3 \%$ se informó como víctimas de abuso sexual; $20.3 \%$ se declaró casado o viviendo en una relación estable. Los registros se concentraron en 04 barrios, Guaxuma, Benedito Bentes, Tabuleiro do Martins y Jacintinho. Conclusiones: hubo una prevalencia de embarazo y matrimonio en niñas menores de 14 años y la falta de informes de abuso sexual debido a la presunción de profesionales de la salud.

Descriptores: Poblaciones Vulnerables; Embarazo; Enfermería; Adolescente; Abuso Sexual Infantil. 


\section{INTRODUCTION}

Care for children and adolescents is based on the idea that they are vulnerable individuals, individually and collectively, considering that vulnerability is intrinsic to human beings, especially in its initial phase. Their biopsychic development is under construction, amid to a period of innocence, discovery and dependence, which naturally make them more susceptible to situations and contexts in which the dominance of the strongest over the weakest is present. Therefore, it demands comprehensive attention for the prevention of situations that possibly have consequences, whether by negligence, discrimination, exploitation, violence, cruelty or oppression ${ }^{(1-3)}$.

Adolescent pregnancy is an expressive phenomenon in Brazil, being a product of this vulnerability. It generates risks to biological (maternal-fetal risks), psychological (insecurity, fear) and social (socioeconomic compromise, family breakdown, school dropout) development as a result of early sexual initiation, which makes the growing increase in the representation of children and adolescents aged 10 to 14 years, in these pregnancies. Biological and psychological immaturity during this phase of transition between childhood and adulthood increase exposure to these risks ${ }^{(4-6)}$.

The Brazilian judicial system recognizes children and adolescents under the age of 14 as a public that demands legitimate criminal protection against any and all types of early sexual initiation to which they are subjected by an adult, in view of the unpredictable risks to the future development of their personality and the inability to measure the physical and psychological scars resulting from a decision that an adolescent or child is not yet able to make ${ }^{(7)}$.

Law 12,015/2009, which provides for heinous crimes and includes sexual crimes against the vulnerable in this category, establishes that performing sexual acts or performing any libidinous act with or in the presence of a child under 14 is a sexual crime against the vulnerable, regardless of consent, obeying the legal justification that the vulnerable does not have the necessary discernment to practice the act, or that, for some reason, cannot offer resistance ${ }^{(7)}$.

The Brazilian legislator's definition of the age of less than 14 years was established based on the principle "Qui velle non potuit, ergo noluit" (translation, "Who cannot want, does not want, who cannot consent, dissent"). Moreover, health and human sciences professionals define this age group as the stage in which psychophysiological changes linked to sexual maturation occur. Countries like Germany and Italy also adopt the same age, differently from other countries like Argentina and Paraguay, which establish the limit of 12 years as a vulnerable minor ${ }^{(8)}$.

According to the Brazilian Penal Code, the vulnerability of children under 14 does not allow relativization, regardless of the victim's consent, past sexual experiences (even in cases of child prostitution) or romantic relationship between author and victim. They are people still in cognitive, hormonal and psychological development with regard to sexuality ${ }^{(2,7)}$.

This study becomes relevant due to the need for visibility of the vulnerability factors surrounding the under-14s, through investigation, reception, and reporting of confirmed or presumed cases of sexual violence by health professionals. They will favor discussion between legal and assistance aspects, expand the implantation of prevention and recovery interventions aimed at reducing these factors, whether from social or biological aspects. Therefore, children and adolescent well-being is one of the goals of caring by these professionals( ${ }^{(9)}$.

\section{OBJECTIVES}

To investigate the presumption of sexual violence through the records of live births with mothers up to 13 years old in the city of Maceió, State of Alagoas.

\section{METHODS}

\section{Ethical aspects}

The study was submitted to the Universidade Federal do Alagoas's Ethics Committee, being approved on 02/02/2018. As it involved the use of secondary nominal data of non-public domain, the Research Ethics Committee (REC) was asked to waive the Informed Consent Term (ICT), committing to comply with the information confidentiality term. Nominal data use was necessary so that there was no duplication of subjects during the analysis and to make it possible to cross-check the information with the bank of the Brazilian Notifiable Diseases Information System.

\section{Study design, place and period}

This is an epidemiological study with a quantitative, observational approach, with an ecological design. The main advantages of being an ecological study is the possible union of several epidemiological data from different sources, which favors a broad view of the association between the possible determining and conditioning factors of the group exposed to the studied aspect. In this case, under 14 years old victims of sexual abuse enable a wide study area with savings in time and resources and make it possible to measure the effect of an injury on the health conditions of a given population ${ }^{(10-11)}$.

The city of Maceió, currently composed of 50 neighborhoods, was chosen as the study site, because in 2015 it had $26.8 \%$ of the total population of children under 14 years old in the State of Alagoas and represented $51 \%$ of the records of live births during the period analyzed in this study ${ }^{(12)}$. Moreover, it had a large part of the reference units for dealing with sexual violence in the sector, composing the protection network for victims.

The research was carried out with data from SINASC involving records of live births from 2009 to 2017. This period was defined based on the date of publication of Law 12,015/2009(7), which, through changes in the penal code for heinous crimes, included sexual crimes against the vulnerable in this category, applying the possibility of presumption of violence in cases of children and adolescents under 14 years old.

\section{Population}

This study included children and adolescents between zero (0) and 13 years, 11 months and 29 days of age classified as vulnerable according to Law 12,015/2009, who were registered at SINASC as mothers of live births in the city of Maceió. 


\section{Exclusion criteria}

Records with information on live births from the same pregnancy (twin) and duplicate records from the same birth were not considered for data treatment.

\section{Study protocol}

Among the study variables, they include the newborn birth date, registration year, mother age, parturient name, Live Birth Declaration number, declared marital status, father age, neighborhood of residence, number of prenatal care appointments, number of previous pregnancies and gestational weeks at delivery.

As the data available at SINASC refer to the age group including the age of 14 years, which was not of interest in that study, all records with mothers aged 14 years were removed, which represented $74.9 \%(3,146)$ of the records. Subsequently, for the exclusion criteria screening, the following variables were analyzed: parturient name, parturient birth date, Declaration of Live Births number, date of birth of the newborn and number of fetuses during pregnancy. The need to check the variable"number of fetuses during pregnancy" occurred so that in twin pregnancy situations, it was not counted twice.

\section{Analysis of results and statistics}

After being collected in digital media, the data were subjected to review and screening for duplicate records. Statistical analysis was performed using the Statistical Package for Social Sciences software (SPSS). In the geoprocessing of the results, the Brazilian National Institute for Space Research (Instituto Nacional de Pesquisas Espaciais, abbreviated INPE) - TerraView program was used, because it is an application for visualization and analysis of geographic data, enabling the visualization of the distribution of cases by the city studied.

For analysis of descriptive statistics, measures of position and central tendency, variability and regression were used. For the applied tests, the level of significance was $5 \%$.

\section{RESULTS}

Nine hundred fifty-three live births were registered with mothers under 14 years old, ranging from 10 to 13 years, with the age of 13 and 12 years being the most representative, $86.6 \%$ and $11.5 \%$, respectively. The results revealed that the average age was 12.8 with a minimum of 10 years $( \pm 0.439)$, thus showing a considerably low age range.

When performing the nominal crossing between the database of the Live Birth Information System (Sistema de Informação sobre Nascidos Vivos, abbreviated SINASC) with the Notified Diseases Information System (Sistema de Informação de Agravos Notificados, abbreviated SINAN). In relation to the victim of sexual abuse from 0 to 13 years old, it was possible to highlight that among the number of girls who entered the Brazilian Unified Health System (Sistema Único de Saúde) due to childbirth under the age of 14, only $14(1.3 \%)$ were reported as victims of sexual abuse at SINAN.

Table 1 shows that $78.3 \%$ of mothers of live births declared to be single, while $20.3 \%$ consist of married or in a stable relationship. A percentage of 0.1 declared to be separated or widowed. When analyzing the father's age variable, $\mathrm{n}$ reduced considerably to 127 cases, which represents $86.6 \%$ of this information not recorded in the declaration of live births. Among those registered, it was found that $50 \%$ of the children's parents were over 20 years old.

Another important aspect is related to the obstetric history of these girls. Table 1 also shows that $5.6 \%$ of the girls have already experienced another pregnancy under the age of $14,15.9 \%$ had a premature birth and that $74 \%$ of the mothers had at least one prenatal care appointment before of delivery, showing a distribution of the number of the same symmetricals in relation to their average. On average, girls have 5.6 prenatal care appointments during pregnancy, but $50 \%$ of them had fewer than six appointments.

Table 1 - Distribution of mothers under 14 years old registered in SINASC, Maceió, Alagoas, Brazil, 2009 to 2017

\begin{tabular}{lcc}
\hline Characteristics of mothers under 14 years old & N & $\%$ \\
\hline Declared marital status & 746 & 78.3 \\
$\quad$ Single & 11 & 1.2 \\
Married & 1 & 0.1 \\
Widow & 1 & 0.1 \\
$\quad$ Separated & 185 & 19.4 \\
$\quad$ Common-law marriage & 9 & 0.9 \\
$\quad$ lgnored & 688 & 72.2 \\
Previous pregnances & 53 & 5.6 \\
$\quad$ None & 212 & 22.3 \\
$\quad$ or more & & \\
$\quad$ Ignored & 6 & 0.6 \\
Number of prenatal care appointments & 476 & 49.9 \\
$\quad$ None & 230 & 24.1 \\
$\quad$ to 6 & 241 & 25.3 \\
$\quad<6$ & & \\
$\quad$ Ignored & 152 & 15.9 \\
Gestational weeks at the time of childbirth & 801 & 84.1 \\
$\quad$ Up to 36 weeks & & \\
$\quad$ 36 weeks &
\end{tabular}

The analysis of this variable allowed to reveal that $74 \%$ of the girls under 14 years old who had children born alive between 2009 and 2017 had at least one contact with health professionals, and even so sexual violence reporting was present in only $1.3 \%$ of cases.

When analyzing the records of live births from 2009 to 2017, in order to assess the presumed violence in these girls, it was identified through linear regression that, despite the occurrence of a $4.9 \%$ reduction in the growth rate regarding the number of live births with mothers under 14 years old between the years analyzed, a weak linear correlation was identified.

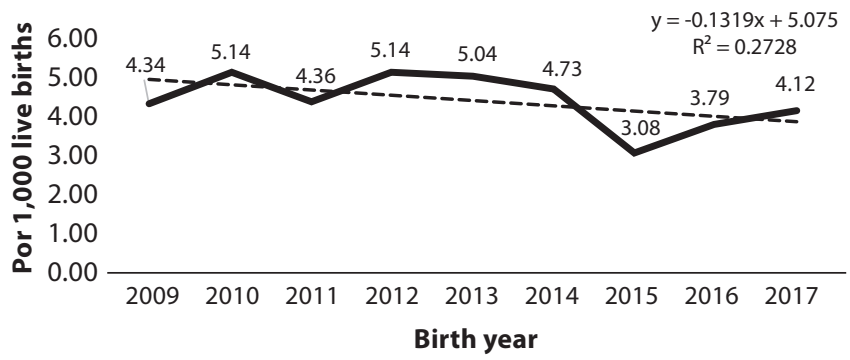

Figure 1- Linear regression by the proportion of live births to mothers under 14 years old by the total number of live births according to the years of birth, Maceió, Alagoas, Brazil, 2009 to 2017 
Regarding the distribution of live births to mothers under 14 years old, according to the neighborhood of residence, it is observed through the map that represents the geographic space of the city of Maceió, that $20 \%$ (10) of the neighborhoods of Maceió did not present records at SINASC. There is also a concentration in nine neighborhoods (18\%) of residence of these mothers in which the number of births varied from 11 to 55 . It is shown on the map that four neighborhoods concentrate a distribution between 44 and 55 live births, they are Guaxuma, Benedito Bentes, Tabuleiro do Martins, and Jacintinho.

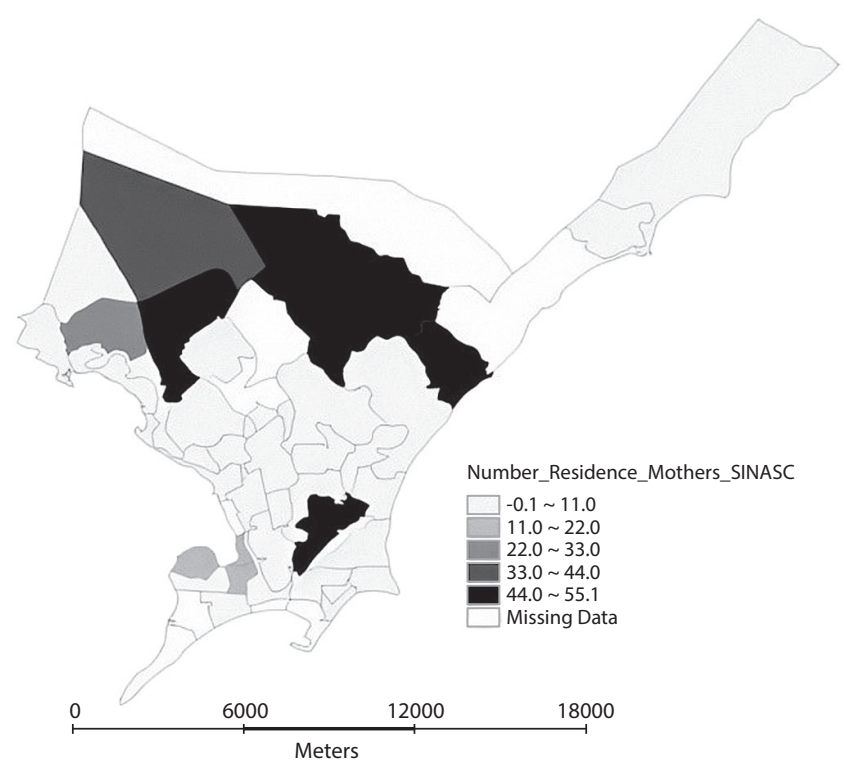

Figure 2 - Map of the distribution of presumed sexual abuse according to SINASC's records by the place of residence of mothers under 14 with children born alive between 2009 and 2017, Maceió, Alagoas, Brazil

\section{DISCUSSION}

Based on the results, it can be seen that 953 live births were from pregnancies involving girls under 14 years old, among them a portion of $74 \%$ had at least one prenatal care appointment and $24.1 \%$ did not reach the minimum amount recommended by the Ministry of Health, which corresponds to a minimum of six appointments. Among them, only $1.3 \%$ were reported at SINAN as sexual abuse violence.

It is pointed out with this that girls, during her pregnancy, had contacts with health professionals. However, sexual violence report was minimal, thus observing a setting of underreporting of cases by health network professionals who provided assistance to these minors, considering that, in the age group studied, sexual violence is seen as suspected and/or presumed.

In Brazil, through Ministerial Decree ${ }^{(13)}$, it is mandatory for health professionals to report the Municipal Office of sexual violence cases they witness during their professional practice. As an example, we have prenatal care appointments to pregnant girls assisted by nurses in primary care. This is a service that when performed together with qualified listening allows the identification of risk situations, reporting, and individualized assistance. Studies demonstrate $^{(14-15)}$ that the increase in the number of reports favors the visibility of the problem and the training for a consistent and committed service. There is harm when the professional does not know and underreport the situation.

There are studies that reveal that this type of underreporting is common when victims of violence belong to vulnerable groups, such as children and adolescents under 14 years old, in addition to women, homosexuals, the elderly and homeless people. The absence of filling in data is another factor that reveals the lack of knowledge of the professionals responsible for welcoming these victims, which weakens the policy and makes qualified care difficult $t^{(9,16-18)}$, identified by means of ignored or unfilled data.

It is possible to affirm that the situation of vulnerability is present in the entire group of adolescents, however the age range carried out in this study, involving 10 to 13 years old, may include the public most susceptible to lack of information and more exposed to sexual abuse, both for the lack of autonomy to consent to sexual relations and for the fragility in suffering coercion ${ }^{(19)}$.

Viewing children and adolescents as a vulnerable group allows them to know and understand the particularities of these subjects, both individually and as a social group, to articulate network actions and to seek to strengthen citizenship rights and the duty of assistance, which favors coping with situations as they are. the case of sexual abuse, which contributes to the compromise of autonomy as a subject, to the inability to elaborate and incorporate information aimed at your own care, compromising the protection and prevention of your health ${ }^{(3,20)}$.

It should be noted that the system adopted by the Code of Ethics for professions is based on responsibility towards duties and obligations. It is noteworthy that the Codes of Ethics in medicine and nursing, professionals working in the care of these audiences, including prenatal care, expressly condemn the omission or collusion of the professional in the face of situations of violence of any nature, imposing penalties that may result in forfeiture of the right to exercise the profession. Thus, violence reporting omission can be configured as an ethical infraction by these professionals ${ }^{(21-22)}$.

Some authors define the importance of reporting when welcoming victims. A study that made it possible to analyze the protection network flows against violence against children through reporting, carried out in $2018^{(23)}$, defines reporting as one of the pillars of the fight against child violence and highlights its potential to define measures of preventing recurrence and establishing a line of care for victims. Another study ${ }^{(16)}$, which analyzed health professionals' Codes of Ethics, regarding the responsibility to report cases of violence against children and adolescents, stated that reporting should work and be viewed as an instrument for the construction of public policies, contributing to their dimensioning and ensuring the implantation of public policies for surveillance and assistance to victims.

Both of the aforementioned studies ${ }^{(16,23)}$ argue that the prevention of sexual abuse is highly relevant, as they act directly in reducing the incidence, in combating recurrences, in manipulating the quality of life, in the high costs of care services and incidence of early pregnancy and contamination by Sexually Transmitted Infections.

It is necessary to provide guidance to health professionals inserted in the network of attention to this public, that reporting 
is not synonymous with denunciation. In the case of children and adolescents who are victims of sexual abuse, only suspicion is sufficient to carry out the reporting ${ }^{(9)}$. In this phase, sexual intercourse is not always a conscious decision, in which the risks and consequences involved were evaluated, even though relationships said to be consented or accepted, often the adolescent has little control over the sexual initiation event, existing a power relationship between the oppressing adult and the oppressed child or adolescent ${ }^{(24)}$.

It is possible to discuss this when we observe that the data revealed that among mothers under 14 years old, $20.6 \%$ declare that they are married or in some type of stable union, which brings up a discussion about the acceptance of marital/sexual relationship and the prevalence of pregnancy involving girls under 14 in Maceió.

According to UNICEF (United Nations Children's Fund), formal or informal union before the age of 18 is defined as child marriage, although studies show that marriage before the age of 18 is a violation of the fundamental rights of children and adolescents, affecting the educational, socioeconomic and physiological development, in a more disproportionate way in girls than boys ${ }^{(19,25-26)}$. It is possible to see that child marriage is still very present in developing countries, where $1 / 3$ of the girls are married before the age of 18 and, for every nine girls, a "house" before the age of $15^{(26)}$.

According to the Brazilian Civil Code, the nubile age, that is, the minimum legal age for marriage, corresponds to 16 years, for both men and women, and Bill 56/2018, which prohibits marriage with under 16 , regardless of the circumstances, without relativization, even in situations involving pregnancy ${ }^{(27)}$.

However, between 16 and 18 years old, as they are considered relatively incapable, these adolescents need to be assisted by their parents or guardians. Therefore, because they are seen before the Brazilian judiciary as a vulnerable group due to numerous factors, among them the progression of sexual maturation, minors under 14, according to the majority doctrine, are prevented from marrying. Furthermore, a sexual relationship is only morally legitimate when both parties have the ability to consent, which the child under 14 does not have ${ }^{(7,19,28-29)}$.

Taking into account legal issues, pregnancy underreporting in children under 14 contacted in this study reveals that health professionals naturalize pregnancy and marriage in this group, ignoring their particularities and treating them as adults, not viewing the imbalance of discernment in this context and the consequences they have entailed.

Adolescent pregnancy, unfortunately, is an expressive phenomenon in Brazil, with growing concern due to the number of records of live births involving mothers between 10 and 14 years old, a group of greatest gestational vulnerability, for both mother and baby. Among the analysis, this was seen when it was identified that $15.9 \%$ of births were premature, similar to other studies, which may be associated with lack of support in the monitoring of pregnancy, biological immaturity, fragility in the family structure, enhanced when associated with socioeconomic and geographic factors ${ }^{(4,30-31)}$.

Although the literature is broader about teenage pregnancy involving the 15 to 19 year old age group, studies indicate that recently the inclusion of the 10 to 14 year old population segment as a growing reproductive age, associated with the social vulnerability in which they are inserted and in consequent repercussions, has been demonstrated in several parts of the country, with the northeast standing out among the regions $\mathrm{s}^{(19,24,32-34)}$.

Georeferencing, present in that work, made possible the presumption of sexual violence according to the neighborhood of residence. It was revealed that among the neighborhoods with the most reports, two of them are among the five neighborhoods considered the most violent in the capital, Benedito Bentes and Tabuleiro do Martins. There is the need for preventive actions in the region with a focus on children and adolescents in the community, planning and implanting policies structured according to the particularities of the public that will benefit and the locations in which they are located ${ }^{(35)}$.

Specialized care is required from professionals involved in assisting to these victims, allowing compulsory reporting to work as an instrument to favor protection, prevention, identification and monitoring by health, social assistance and justice professionals, in order to strengthen identifying vulnerabilities and adopting measures to care for these victims. Therefore, reporting implies sharing and sharing with different branches of society the responsibility to protect our children and adolescents.

\section{Study limitations}

As with all types of studies, ecological studies have limitations, among those present in this study we find the unavailability of total information on all variables analyzed, due to the lack of data and the impossibility of an association between exposure and the individual health status of the subjects, which limits the conclusions about the cause of the disease. This limitation is called the ecological fallacy ${ }^{(10-11)}$.

\section{Contributions to nursing}

It is believed that nurses need to have scientific knowledge about the problem of violence in order to fulfill their responsibility in relation to professional assistance, taking over the role of caregiver, that of educator, showing the family, at any time, the ideology of protection of rights children and adolescents, emphasizing the prevention of the event and recurrence.

Thus, the study reveals that it is necessary to deepen the dissemination and understanding of the discussions involving the issue of violence against children and adolescents, whether reported or presumed, so that nurses use the scientific knowledge built to urgently face the challenge of detecting, reporting, caring for, minimizing, and preventing situations of violence against children and adolescents.

\section{CONCLUSIONS}

The results obtained in this study showed that 953 children were born to mothers aged 10 to 13 years, with only $1.3 \%$ of these mothers being reported as victims of sexual abuse. Associated with this fact, it was possible to verify that child marriage is still a very present reality in the city of Maceió (20.6\%), which reveals 
that pregnancy in girls up to 13 years old is not identified by health professionals as a result of sexual abuse, regardless of whether the pregnancy is due to a relationship said to be consensual or not, which accentuates issue underreporting and (in) visibility. Therefore, it is necessary to debate the issues of sexuality and gender involved in sexual initiation of pre-teenagers.

\section{FUNDING}

The research carried out to build the aforementioned manuscript received funding from Research Support Foundation of the State of Alagoas (FAPEAL - Fundação de Amparo à Pesquisa do Estado de Alagoas).

\section{REFERENCES}

1. Presidência da República (BR). Decreto n 7.958, de 13 de Março de 2013. Estabelece diretrizes para o atendimento às vítimas de violência sexual pelos profissionais de segurança pública e da rede de atendimento do Sistema Único de Saúde. Brasília [Internet]. 2013 [cited 2018 Nov 13]. Available from: http://www.planalto.gov.br/ccivil_03/_ato2011-2014/2013/decreto/d7958.htm

2. Faria AAM, Vianna T. Maioridade Sexual: por uma idade de consentimento sexual pautada na tutela de bens jurídicos. Rev Bras Ciênc Crim[Internet]. 2016 [cited 2018 Feb 10];118:15-54. Available from: http://bdjur.stj.jus.br/jspui/handle/2011/99346

3. Carmo ME, Guizardi FL. O conceito de vulnerabilidade e seus sentidos para as políticas públicas de saúde e assistência social. Cad Saúd Púb. 2018;34(3):e00101417. doi: 10.1590/0102-311×00101417

4. Farias R, Moré COO. Impact of pregnancy on at-risk, 10-14 year-old adolescents. Rev Psicol: Reflex Crít[lnternet]. 2012 [cited 2018 Jan 28];25(3):596-604. doi: 10.1590/S0102-797222012000300020

5. World Health Organization (WHO). Health for the world's adolescents: a second chance in the second decade [Internet]. 2014 [cited 2017 Nov 01]. Available from: http://www.who.int/maternal_child_adolescent/documents/second-decade/en/

6. Santos MJ, Mascarenhas MDM, Rodrigues MTP, Monteiro RA. Caracterização da violência sexual contra crianças e adolescentes na escolaBrasil, 2010-2014. Rev Epidemiol Serv Saúde [Internet]. 2018;27(2):e2017059. doi: 10.5123/S1679-49742018000200010

7. Presidência da República (BR). Lei Federal n. 12.015, de 7 de agosto de 2009. Altera o Título VI da Parte Especial do Decreto-Lei no 2.848, de 7 de dezembro de 1940 - Código Penal, e o art. 1 o da Lei no 8.072, de 25 de julho de 1990, que dispõe sobre os crimes hediondos, nos termos do inciso XLIII do art. 5 o da Constituição Federal e revoga a Lei no 2.252, de 1 o de julho de 1954, que trata de corrupção de menores [Internet]. Brasília 2009 [cited 2017 May 03]. Available from: http://www.planalto.gov.br/ccivil_03/_Ato20072010/2009/Lei/L12015.htm

8. Carvalho ACBO. Violência sexual presumida. Curitiba: Juruá, 2005. 23 p.

9. Garbin CAS, Dias IA, Rodovia TAS, Garbin AJl. Desafios do profissional de saúde na notificação da violência: Obrigatoriedade, efetivação e encaminhamento. Ciênc Saúde Colet [Internet]. 2015;20(6):1879-1890. doi: 10.1590/1413-81232015206.13442014

10. Medronho RA. Estudos ecológicos. In: Medronho RA, et al. Epidemiologia. São Paulo: Atheneu; 2009. 265-74 p.

11. Hulley SB, Cummings SR, Browner W, Grady DG, Newman TB. Delineando a pesquisa clínica: Uma abordagem epidemiológica. Porto Alegre: Artmed, 2015. 47-80 p.

12. Ministério da Saúde (BR). Departamento de Informática do SUS. Sistema de Informação de saúde. [Internet]. Datasus. 2018 [cited 2018 jan 20]. Available from: http://datasus.saude.gov.br/informacoes-de-saude/tabnet.

13. Ministério da Saúde (BR). Portaria n²04, de 17 de fevereiro de 2016. Define a Lista Nacional de Notificação Compulsória de doenças, agravos e eventos de saúde pública nos serviços de saúde públicos e privados em todo o território nacional, nos termos do anexo, e dá outras providências[Internet]. 2016 [cited 2019 Feb 01]. Available from: http://bvsms.saude.gov.br/bvs/saudelegis/gm/2016/prt0204_17_02_2016.html

14. Alves JM, Vidal ECF, Fonseca FLA, Vidal ECF, Silva MJ, Pinto AGA, et al. Notificação da violência contra criança e adolescentes por profissionais de saúde. Rev Fac Ciênc Méd. 2017;19(1):26-32. doi: 10.5327/Z1984-4840201726596

15. Ministério da Saúde (BR). Secretaria de Atenção à Saúde. Departamento de Atenção Básica. Atenção ao pré-natal de baixo risco [Internet]. 2013 [cited 2018 Dec 03]. Available from: http://189.28.128.100/dab/docs/portaldab/publicacoes/caderno_32.pdf

16. Almeida AHV, Silva MLCA, Musse JO, Marques JAM. A responsabilidade dos profissionais de saúde na notificação dos casos de violência contra crianças e adolescentes de acordo com seus códigos de ética. Arq Odontol [Internet]. 2012 [cited 2018 Jun 16];48(2):102-15. Available from: http://revodonto.bvsalud.org/pdf/aodo/v48n2/a08v48n2.pdf

17. Mascarenhas MDM, Andrade SSCA, Neves ACM, Pedrosa AAG, Silva MMA, Malta DC. Violência contra pessoa idosa: análise das notificações realizadas no setor de saúde. Ciênc Saúde Colet [Internet]. 2012;17(9):2331-2341. doi: 10.1590/S1413-81232012000900014

18. Meneghel SN, Bairros F, Mueller B, Monteiro D, Oliveira LP, Collaziol ME. Rotas críticas de mulheres em situação de violência: depoimentos de mulheres e operadores em Porto Alegre, Rio Grande do Sul, Brasil. Cad Saúde Púb. 2011;27(4):743-52. doi: 10.1590/ S0102-311X2011000400013

19. Cavasin S, (Org.). Gravidez entre adolescentes de 10 a 14 anos: estudo exploratório em cinco capitais brasileiras e vulnerabilidade social: relatório de pesquisa. São Paulo: ECOS; 2004. p. 13-35.

20. Egry EY, Apostólico MR, Morais TCP, Lisboa CCR. Coping with child violence in primary care: how do professionals perceive it? Rev Bras Enferm. 2017;70(1):113-9. doi: 10.1590/0034-7167-2016-0009 
21. Conselho Federal de Enfermagem. Resolução COFEN n 564, de 06 de novembro de 2017. Reformulação do Código de Ética dos Profissionais de Enfermagem[Internet]. 2017 [cited 2018 Dec 06]. Available from: http://www.cofen.gov.br/resolucao-cofenno-5642017_59145.html

22. Conselho Federal de Medicina. Resolução CFM n 2.217, de 01 de novembro de 2018. Aprova o Código de Ética Médica[Internet]. 2018 [cited 2018 Dec 06]. Available from: http://portal.cfm.org.br/images/PDF/cem2019.pdf

23. Egry EY, Apostolico MR, Morais TCP. Notificação da violência infantil, fluxos de atenção e processo de trabalho dos profissionais da Atenção Primária em Saúde. Ciênc. Saúde Colet. [Internet]. 2018; 23(1):83-92. doi: 10.1590/1413-81232018231.22062017.

24. Rede Nacional da Primeira Infância (RNPI). Primeira Infância e gravidez na Adolescência. Centro de Estudos integrados: infância, adolescência e Saúde [Internet]. 2015 [cited 2019 Feb 02]. Available from: http://primeirainfancia.org.br/wp-content/uploads/2015/01/ Cartilha-Gravidez-Adol-FINAL-HD.pdf

25. UNICEF. State of the World's Children. New York: UNICEF [Internet]. 2013 [cited 2018 Dec 12]. Available from: https://www.unicef.org/ sowc2013/

26. Tascón LAM, Benítez DIC, Tascón LIM, Ospina CBP, Guatibonza MDA, Bejarano JHC, et al. Matrimonio infantil: un problema social, económico y de salud pública. Rev Child Obstet Ginecol. 2016;81(3):254-61. doi: 10.4067/S0717-75262016000300013

27. Brasil. Projeto de Lei n 56/2018. Confere nova redação ao art. 1.520 da Lei no 10.406, de 10 de janeiro de 2002 (Código Civil), para suprimir as exceções legais permissivas do casamento infantil. Brasília [Internet]. 2018 [cited 2019 Feb 15]. Available from: https://www25.senado. leg.br/web/atividade/materias/-/materia/133561.

28. Câmara dos Deputados (BR). Código Penal Brasileiro. Lei 11.106/2005: Altera os arts. 148, 215, 216, 226, 227, 231 e acrescenta o art. 231-A ao Decreto-Lei no 2.848, de 7 de dezembro de 1940 - Código Penal e dá outras providências. Brasília [Internet]. 2005 [cited 2019 Feb 10]. Available from: http://www.planalto.gov.br/ccivil_03/_Ato2004-2006/2005/Lei/L11106.htm.

29. Nogueira RM. A evolução da sociedade patriarcal e sua influência sobre a identidade feminina e a violência de gênero. Rev Jus Navigandi [Internet]. 2016 [cited 2018 Oct 11]; 23(5377). Available from: https://jus.com.br/artigos/48718

30. Costa EL, Sena MCF, Dias A. Gravidez na adolescência: determinante para prematuridade e baixo peso. Comun Ciênc Saúde [Internet]. 2011 [cited 2018 Sep 20];22(Sup-1):183-8. Available from: http://bvsms.saude.gov.br/bvs/artigos/gravidez_adolescencia.pdf

31. Souto RMCV, Porto DL, Pinto IV, Vidotti CCF, Barufaldi LA, Freitas MG, et al. Estupro e gravidez de meninas de até 13 anos no Brasil: características e implicações na saúde gestacional, parto e nascimento. Ciênc Saúde Colet. 2017;22(9):2909-18. doi: $10.1590 / 1413-81232017229.13312017$

32. Costa RP. Gilberto Freyre e a infância no Brasil patriarcal. Angelus novus [Internet]. 2015 [cited 2018 Sep 22];6(10):41-60. Available from: http://www.revistas.usp.br/ran/article/view/123940/120178

33. Pedro Filho F, Sigrist RMS, Souza LB, Mateus DC, Rassam E. Perfil epidemiológico da grávida adolescente no município de Jundiaí e sua evolução em trinta anos. Adolesc Saúde [Internet]. 2011 [cited 1019 Jan 10];8(1):21-27. Available from: http://www.adolescenciaesaude. com/detalhe_artigo.asp?id=261

34. Catalenti FR, Freitas FP, Cano MAT. Partos na pré-adolescência em uma cidade do interior paulista. Investigação. 2015;14(1):133-137. doi: 10.26843/investigacao.v14i1.727

35. Secretária de Estado de Prevenção à Violência-SEPREV. Relatório da Violência no Estado-Alagoas [Internet]. 2016 [cited 2019 Feb 14]. Available from: http://www.seprev.al.gov.br/sala-de-imprensa/noticias/2016/maio/ relatorio-da-seprev-aponta-os-bairros-mais-violentos-de-maceio-confira 